\title{
SMES EMPLOYEE, PERSON-ORGANIZATION FIT, AND ORGANIZATIONAL CITIZENSHIP BEHAVIOUR
}

\author{
Faidal \\ faidal@trunojoyo.ac.id \\ Lecture of Management, Faculty of Economics and Business, Trunojoyo Madura \\ University
}

\begin{abstract}
SMEs will get the maximum production when their employee get work satisfaction. They will work efficient when their workplace is comfortable. So the objective of this research is to analyze the influence of the workplace and Person-Organization Fit to Organizational Citizenship Behaviour (OCB) through employee satisfaction as a variable intervening at the Indonesia SMEs. This study using a random sampling of employees of Indonesia SMEs with the number 250 employees of SMEs. Instruments that are used in this research is a questionnaire to obtain the primary data needed. The research method is quantitative analysis, the data obtained is based on the answers from respondents on the questionnaire, analyzed by statistical techniques of multiple linear regression analysis, the regression model is tested with classical assumptions to meet the requirements and is suitable to be used to predict the effect of independent variables on the dependent variable. The results of the regression calculations were tested using the t-test and the coefficient of determination. The research finding have shown that variable Workplace and person-organization Fit influential to Organizational Citizenship Behaviour through employee satisfaction on the employees of Indonesia SMEs. In research, it is known that the Workplace is a variable independent that influences the most substantial of the Organizational Citizenship Behaviour of employees compared to variable independent else.
\end{abstract}

Keywords: Workplace, Person-Organization Fit, Organizational Citizenship Behaviour.

\section{INTRODUCTION}

The source of the power of man covers a whole human that exists in the organization from the lowest level down to the level of the top. Although different levels will be all these sources of power of man that have a role that is similar and significant to reach the purpose of the organization (Ernie, 2005). SMEs of Indonesia is an organization that has the purpose of implementing the empowerment of communities through programs of certain. Based on the results of interviews were conducted with the employee of SMEs, note that one of the things that becomes a problem in SMEs Indonesia is the least number of employees that work. Besides that, the burden of work that is given by each employee very much so they have to be willing to do the work with the system over 
time. Today work for all employees in Indonesia SMEs an average of six days of work started monday until Saturday with hours of work effectively start at 07.00 AM up to 04.00 PM. However, Indonesian SMEs employee often do overtime until late at night. Some employees are also required to keep departing on Saturday to finish the work that has been given. The presence of the four areas of work in Indonesia SMEs and is still a lack of personnel clerks make the employees are required to have the behaviour of OCB are high.

Based on the results of interviews that have been conducted with the employee of SMEs, note that the Indonesia SMEs employee have the OCB behaviour. It as evidence always show behaviour that is positive as helping colleagues work in completing the task, giving information among employees in the field, active in the activities of the office, acting by the procedure, and provide the best service. Factors that influence the OCB in SMEs including workplace.

The phenomenon of a workplace at Indonesia SMEs is the fact that they work by a group/team, so without realizing the closeness them into a relationship that is very beneficial for the organization. According to the interviews were conducted with the employees of SMEs, known to the employees in Indonesia SMEs look to coordinate the action they are to be good. They always establish communication with the well and socialize related issues job. They do things that also because of the awareness towards the appropriateness of objectives and needs of fellow co-working with the organization of the place where they work. The suitability of the goals between the individual and the organization, in this case, is the leader and co-workers or commonly known as personorganization fit (PO Fit).

The PO Fit phenomenon in Indonesian SMEs can be seen from the individual characteristics which include behaviour, attitudes, education, and values. The behaviour and attitude of employees in Indonesia SMEs into the characteristics the most visible in measuring the level of conformity of the individual with the organization. The behaviour of employees who continue to demonstrate a sense of pleasure in the work so that the work can be completed with either can be a characteristic of the suitability of interest with the organization. The most dominant value conformity between employees and Indonesian SMEs is the value of cooperation and the value of their love for nature.

Feeling comfortable and happy in doing a job well is a satisfaction for the employees before led to behaviour OCB. Work satisfaction is a determinant important that encourages the person showing the behaviour of the $\mathrm{OCB}$, caused for individuals who get satisfaction in the job, will tend to interpret the work and duties which he carried out with full responsibility and dedication.

\section{LITERATURE REVIEW}

\subsection{Organization Citizenship Behaviour (OCB)}

Organization Citizenship Behaviour (OCB) is an individual contribution that exceeds the demands of a role in the workplace and is rewarded based on individual 
performance results. OCB involves some behaviours include behaviours that help one another, become a volunteer for tasks extra, obedient to the rules and procedures in place work.

Organ (1998) states that there are five dimensions of Organization Citizenship Behaviour, namely:
1. Altruism
2. Civic Virtue
3. Conscientiousness
4. Courtesy
5. Sportsmanship

\subsection{Workplace}

Berman et al., (2002) define a workplace as a relationship work nontransferable be voluntary which involves a sense of mutual trust, commitment, desire lead back and the interests and values together. Dotan (2007) argued when employees have a friend who can be trusted in the place of work, they can obtain assistance or advice from colleagues work friend them and, therefore, obtain a feeling safe, comfortable, and satisfied with the work they are in a place of work.

The workplace indicators according to Nielsen (2000) include Measurement of the workplace dimensions of opportunity:

1. Get to know co-workers

2. Working as a collective

3. Free to communicate

4. Organizational support

5. Relationship closely

6. Tolerance

Workplace prevalence dimension measurement:
1. Intimacy
2. Socialization
3. Share stories
4. Trust
5. Motivation
6. Neutral

\subsection{Person-Organization Fit (PO Fit)}

Kristof-Brown and Billsberry (2013), defines PO Fit as conformity between people and organizations, which occurs when at least one party provides the needs of the other, or both parties share the characteristics underlying the same.

The PO Fit indicators according to Kristof (1996) include:

1. Suitability value (value congruence) 
2. The suitability of goals (goal congruence)

3. Meeting the needs of employees

4. The suitability of the characteristics of the personality culture

\subsection{Employee satisfaction}

The employee satisfaction according to Robbins (2003), is an attitude common to the work of a person, which shows the difference between the number of awards were received by the workers and the amount that they believe should they receive.

The employee satisfaction indicators according to Robbin (2009) include:

1. Satisfaction of the work it themselves

2. Satisfaction of the remuneration of the work that

3. Satisfaction with supervision from superiors

4. Satisfaction of the co- working

5. Satisfaction with promotion

Empirical Model

Based on base theories that have been discussed, it can be prepared a model of empirical which is described as follows:

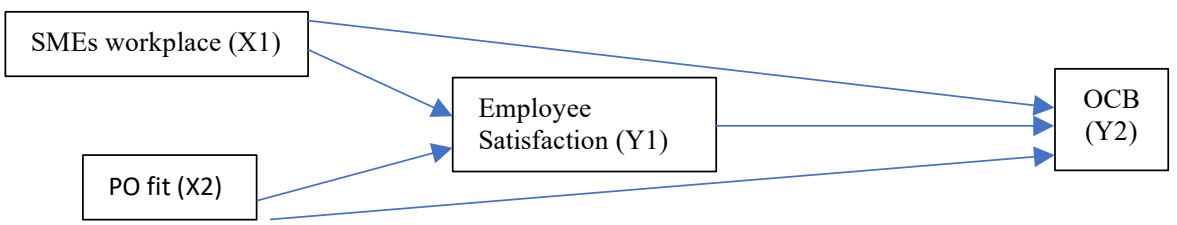

Figure 1. Empirical Model

\section{RESEARCH METHOD}

The design of the study is to use testing hypotheses and research is to use the type of research quantitatively. The population of the study is the whole employees of Indonesia SMEs and methods of taking samples using the technique of non-probability sampling that the sample is saturated with the number of 50 employees.

Techniques of collecting data are done by way of (1) Spread the questionnaire directly to the employees of Indonesia SMEs ; (2) interview ; (3) Literature study. Instruments in the research are done by using a questionnaire which indicated to obtain answers from the respondents. Tools processing the data using SPSS for Windows version 22.0 Technical analysis of the data is done in two ways, namely the analysis of descriptive and analytical statistics. Analysis of the data by statistical includes (1) test the validity and reliability; (2) Classical Assumption Test; (3) Hypothesis testing; (4) Correlation Analysis; (5) Path Analysis. 


\section{Reliability Test}

\section{DISCUSSION}

Test reliability is done with provisions if $\mathrm{r}$-alpha $>0.70$, then the variables are reliable.

Table 1. Reliability Test Result

\begin{tabular}{l|c|c|c}
\hline \multicolumn{1}{c|}{ Variable } & $\begin{array}{c}\text { Value } \\
\text { of } \\
\text { Alpha }\end{array}$ & $\begin{array}{l}\text { Critic } \\
\text { al } \\
\text { Value }\end{array}$ & $\begin{array}{l}\text { Conclus } \\
\text { ion }\end{array}$ \\
\hline Workplace & 0.81 & 0. & Reliable \\
$\left(\mathrm{X}_{1}\right)$ & 7 & 6 & \\
\hline PO Fit $\left(\mathrm{X}_{2}\right)$ & 0.81 & 0. & Reliable \\
& 2 & 6 & \\
\hline Employee & 0.85 & 0. & Reliable \\
Satisfaction & 5 & 6 & \\
$\left(\mathrm{Y}_{1}\right)$ & & & \\
\hline OCB $\left(\mathrm{Y}_{2}\right)$ & 0.81 & 0. & Reliable \\
& 0 & 6 & \\
\hline
\end{tabular}

Based on the table above, the results of the analysis can be explained that the entire variables were used in the study is declared reliable because $\mathrm{r}$-alpha $>0.70$.

\section{Classical Assumptions Test}

\section{Multicollinearity Test}

Table 2. Multicollinearity Test Sub-Structural I

\begin{tabular}{l|l|l}
\hline \multirow{2}{*}{ Variable } & \multicolumn{2}{|l}{ Collinierity Statistics } \\
\cline { 2 - 3 } & Tolerance & VIF \\
\hline $\begin{array}{l}\text { Workplace } \\
\left(\mathrm{X}_{1}\right)\end{array}$ & 0.515 & 1.956 \\
\hline PO Fit $\left(\mathrm{X}_{2}\right)$ & 0.512 & 1.956 \\
\hline
\end{tabular}

Tabel 3. Multicollinearity Test Sub-Structural II

\begin{tabular}{l|r|r}
\hline \multirow{2}{*}{ Variable } & \multicolumn{2}{|c}{$\begin{array}{l}\text { Collinierity } \\
\text { Statistics }\end{array}$} \\
\cline { 2 - 3 } & $\begin{array}{r}\text { Toleranc } \\
\mathrm{e}\end{array}$ & \multicolumn{1}{c}{ VIF } \\
\hline $\begin{array}{l}\text { Workplace } \\
\left(\mathrm{X}_{1}\right)\end{array}$ & 0.421 & 2.323 \\
\hline PO Fit $\left(\mathrm{X}_{2}\right)$ & 0.402 & 2.465 \\
\hline
\end{tabular}




\begin{tabular}{l|l|l}
\hline $\begin{array}{l}\text { Employee } \\
\text { Satisfaction } \\
\text { (Y1) }\end{array}$ & 0.401 & 2.479 \\
\hline
\end{tabular}

Based on the table above, the regression model in this study did not occur multicollinearity because the tolerance value was more than 0.1 and the VIF value was less than 10 .

\section{Heteroscedasticity Test}

\section{Scatterplot}

Dependent Variable: Y1

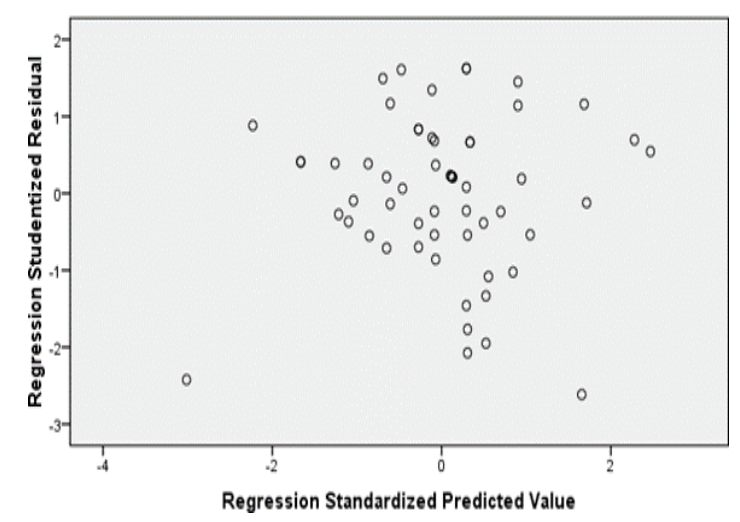

Figure 2. Heteroscedasticity Test, Sub Structural I

\section{Scatterplot}

Dependent Variable: Y1

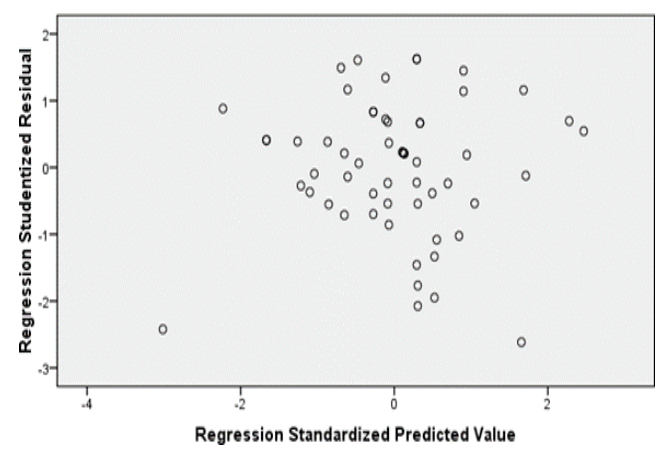

Figure 3. Heteroscedasticity Test, Sub Structural II

Based on the picture above, the model regression in the study is free of heteroscedasticity because it does not exist patterns of particular are clear. 


\section{Normality Test}

\section{Normal P-Plot of Regression Standardized Residual}

Dependent Variable: Y1

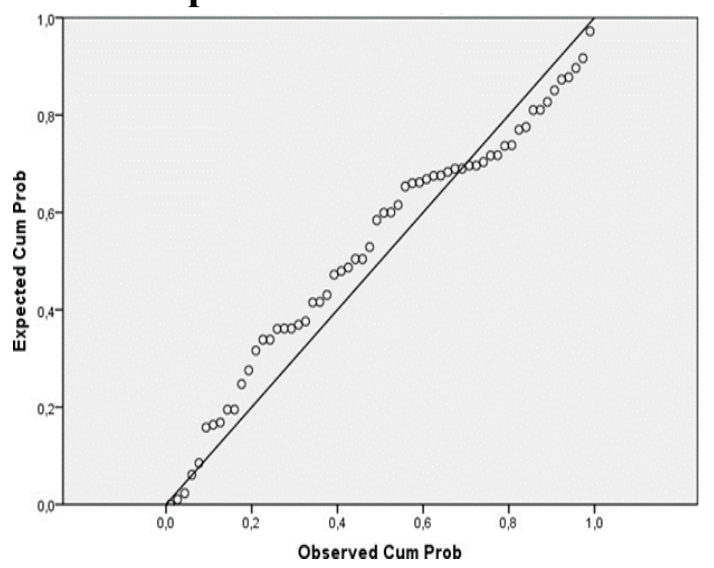

Figure 4. Normality Test, Sub- Structural I

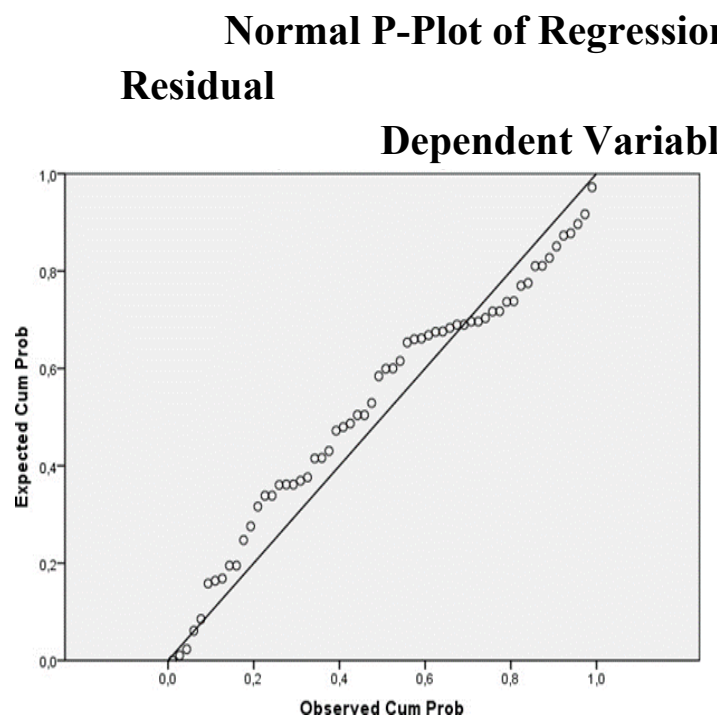

Figure 5. Normality Test, Sub Structural II

Based on the image above, note that the data spread in around diagonal lines and follow direction diagonal line, the models meet the assumptions of normality data.

Hypothesis Test

Partial Test Result

Table 4. t-test, Sub Structural I

\begin{tabular}{|c|c|c|c|c|c|}
\hline \multirow[b]{2}{*}{ Model } & \multicolumn{2}{|c|}{$\begin{array}{c}\text { Unstandardiz } \\
\text { ed } \\
\text { Coefficients }\end{array}$} & \multirow{2}{*}{ 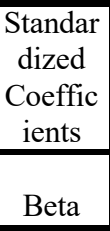 } & \multirow[b]{2}{*}{$t$} & \multirow[b]{2}{*}{ Sig. } \\
\hline & B & $\begin{array}{c}\text { Std. } \\
\text { Error }\end{array}$ & & & \\
\hline $\begin{array}{l}\text { (Cons } \\
\operatorname{tant})\end{array}$ & $\begin{array}{r}1.33 \\
3 \\
\end{array}$ & 2.146 & & .621 & .538 \\
\hline $\mathrm{X} 1$ & .222 & .075 & .384 & 2.766 & .000 \\
\hline $\mathrm{X} 2$ & .531 & .152 & .453 & 3.376 & .001 \\
\hline
\end{tabular}


Based on the table above shows that:

a. Workplace affect positively and significantly to the employee satisfaction for $t$ for $2.766>$ t-table at 2.01290 and significant with the value of the significance is 0.000 .

b. PO Fit influence positively and significantly the employee satisfaction for $t$ for $3.376>t$-table at 2.01290 and significant with the value of the significance is 0.001 , it is smaller than 0.005 .

Table 5. t-test, Sub Structural II

\begin{tabular}{l|r|r|r|r|r}
\hline & \multicolumn{2}{|c|}{$\begin{array}{c}\text { Unstandardi zed } \\
\text { Coefficients }\end{array}$} & $\begin{array}{c}\text { Standar } \\
\text { dized } \\
\text { Coeffic } \\
\text { ients }\end{array}$ & & \\
\cline { 2 - 4 } Model & & $\begin{array}{c}\text { Std. } \\
\text { Error }\end{array}$ & \multicolumn{1}{c|}{ Beta } & $\mathrm{t}$ & Sig. \\
\hline $\begin{array}{l}\text { (Cons } \\
\text { tant }\end{array}$ & 1.694 & 1.968 & & .861 & 0.394 \\
\hline $\mathrm{X} 1$ & 0.245 & 0.074 & 0.397 & 3.297 & 0.002 \\
\hline $\mathrm{X} 2$ & 0.207 & 0.156 & 0.165 & 1.328 & 0.191 \\
\hline $\mathrm{Y} 1$ & 0.401 & 0.133 & 0.374 & 3.012 & 0.004 \\
\hline
\end{tabular}

Based on the table above shows that:

a. Workplace influence positively and significantly to the OCB for $t$ for $3.297>t-$ table at 2.01290 and the value of the significance of $0.002<0.005$

b. b. PO Fit does not affect positively and significantly to the OCB for $t$ for $1.328<$ t-table at 2.01290 and the value of the significance of $0.191>0.05$

c. Employee satisfaction affects positively and significantly to the OCB for $t$ for $3.012<\mathrm{t}$-table at 2.01290 and the value of the significance of $0.004<0.005$

\section{Coefficient of Determination}

Table 6. Determination Test Result

\begin{tabular}{|l|l|}
\hline \multicolumn{2}{|c|}{ Model Summary $^{\mathbf{b}}$} \\
\hline R-square & 0.893 \\
\hline Adj. R-square & 0.795 \\
\hline
\end{tabular}


Based on the output above can be seen the value of Adjusted R Square 0.893, means all variables is influence to model with $89 \%$, and another $11 \%$ is influenced by other variable outside model.

\section{Correlation Analysis}

\begin{tabular}{|c|c|c|c|c|}
\hline & & $\begin{array}{l}\text { Total } \\
\text { X1 }\end{array}$ & $\begin{array}{c}\text { Total } \\
\text { X2 }\end{array}$ & $\begin{array}{c}\text { Total } \\
\text { Y1 }\end{array}$ \\
\hline \multirow{3}{*}{$\begin{array}{l}\text { Tot } \\
\text { al } \\
\text { X1 }\end{array}$} & $\begin{array}{l}\text { Pearson } \\
\text { Correlation }\end{array}$ & 1 & $\begin{array}{r}0.699^{*} \\
*\end{array}$ & $\begin{array}{r}0.701^{*} \\
*\end{array}$ \\
\hline & $\begin{array}{l}\text { Sig. (2- } \\
\text { tailed) }\end{array}$ & & 0.000 & $\underline{0.000}$ \\
\hline & $\mathrm{N}$ & 50 & 50 & 50 \\
\hline \multirow{3}{*}{$\begin{array}{l}\text { Tota } \\
1 \\
\text { X2 }\end{array}$} & $\begin{array}{l}\text { Pearson } \\
\text { Correlation }\end{array}$ & $\begin{array}{r}0.699^{*} \\
*\end{array}$ & 1 & $\begin{array}{r}0.722^{*} \\
*\end{array}$ \\
\hline & $\begin{array}{l}\text { Sig. (2- } \\
\text { tailed) }\end{array}$ & 0.000 & & 0.000 \\
\hline & $\mathrm{N}$ & 50 & 50 & 50 \\
\hline \multirow{3}{*}{$\begin{array}{l}\text { Tot } \\
\text { al } \\
\text { Y1 }\end{array}$} & $\begin{array}{l}\text { Pearson } \\
\text { Correlation }\end{array}$ & $\begin{array}{r}0.701^{*} \\
*\end{array}$ & $\begin{array}{r}0.722^{*} \\
*\end{array}$ & 1 \\
\hline & $\begin{array}{l}\text { Sig. (2- } \\
\text { tailed) }\end{array}$ & 0.000 & 0.000 & \\
\hline & $\mathrm{N}$ & 50 & 50 & 50 \\
\hline
\end{tabular}

**. Correlation is significant at the 0.01 level (2-tailed).

Based on the table above, the value of the correlation of workplace against PO Fit is 0.699 and the number significant is $0.000<0.05$, meaning between variables workplace and PO Fit has a strong correlation and significant.

\section{Implications}

After doing the analysis the author makes the implications of managerial as follows:

1. The workplace effect to employee satisfaction

Based on the results of above, it was obtained that the workplace to the employee satisfaction is significant effect. The influence of the workplace which is significant to the satisfaction of the work identified that the high to low levels of the workplace in Indonesia SMEs do affect the high- low level of satisfaction of the work of the employees. It is because of the level of friendship that exists in Indonesia SMEs is much give contribution to the flavor satisfied at work. 
The results of the study are same from the results of the study were conducted by Reza Asgharian in 2015 with the title The mediating Effect of Employee satisfaction on the Relationship between Workplaces and Turnover Intention in Iran Hotel Industry. Research that stated that the workplace has the effect of significantly to the employee satisfaction.

2. The effect of po fit to employee satisfaction

Based on the results of the t-test was obtained that the PO Fit affects that significant the employee satisfaction. Effect of PO Fit was positive and significant identified that employees already feel fit with the values that exist in Indonesia SMEs, and the purpose of employees by the purpose of the organization. It is marked with the employee who liked the system works with team and his passion to work in a field that is by the value of the SME Indonesia.

\section{Effects of workplace to OCB}

Based on the results of the t-test was obtained that the workplace affects that significant to OCB. The influence of the workplace which is positive and significant identifies that the workplace will be inversely proportional to the OCB. If the workplace has increased, OCB will also experience an increase. The higher the level of friendship in Indonesian SME, the more OCB behaviour will be increased. This is because friendship encourages empathy and can share problems that lead to helping behaviour.

The results of the research are supported by research that is conducted by ChiaMing Chang, et al., In 2018 in his research entitled The Impact of Perceived Supervisor Support and Workplace on Organization Citizenship Behaviour in Support Center. Research that stated that the workplace has the effect of significantly against the OCB.

\section{4. $\quad$ Effect of PO Fit To OCB}

Based on the results of the t-test was obtained that there are influences that are not significant between PO Fit to OCB. PO Fit which does not influence OCB identifies that the high and low level of PO Fit in Indonesian SMEs will not affect the OCB behaviour of employees.

The results of the study are different from the results of the study were conducted by Princess Marita Abdurachman (2017), in his research were entitled Effect Relationship between person-Organization Fit (PO Fit) The Organization Citizenship Behaviour (OCB) On Employee PT. Central Proteina Prima Jakarta. Research that stated that personOrganization Fit (PO Fit) has influence positively and significantly the OCB.

\section{Effect of work satisfaction to OCB}

Based on the results of the t-test was obtained that the workplace affects that significant to OCB. So, the influence of the workplace which is positive and significant identifies that the workplace will be inversely proportional to the OCB. If the satisfaction of the work of employees experienced an increase in the behaviour of the OCB also will experience an increase. It is based on the achievement of a sense satisfied the employees 
in Indonesia SMEs upon completion of all the work the behaviour of OCB as helping colleagues who still have dependents job is fairly high. They will take more initiative and volunteer to help colleagues who need help.

\section{CONCLUSION}

Based on the results of research on the Effects of Workplace and personorganization Fit (PO Fit) against Organizational Citizenship Behaviour (OCB) with Work satisfaction For Variable Intervening which has been discussed as well as the calculation of statistics that do, then the researchers can conclude as follows:

Workplace is positive and significant impact on employee satisfaction in Indonesian SMEs. And also has a positive and significant influence on OCB in Indonesian SMEs.

Person-Organization Fit has no effect on OCB in Indonesian SMEs. Can be concluded that the conformity between the values of the individual with the values of the organization does not influence on the behaviour of OCB employee.

Employee satisfaction has a positive and significant influence on OCB in Indonesian SMEs. This means that the more high level of satisfaction of employees in the work that will improve the behaviour of the OCB of the employee.

Workplace influences OCB through employee satisfaction in Indonesian SMEs. It means that the increasingly high level of friendship at the place of work then it will be an increasingly high level of satisfaction with the work of the employees who are not directly impacted by the behaviour of OCB.

Person-Organization Fit influences OCB through employee satisfaction in Indonesian SMEs. It means that the increasingly high level of suitability values between individuals with the organization will be an increasingly high level of satisfaction with the work of the employees who are not directly impacted by the behaviour of OCB.

\section{SUGGESTION}

For further research is also expected to expand the scope of the research area, so that the research results can be implemented in general.

\section{RESEARCH LIMITATIONS}

This study has not been able to reveal the overall factors that influence OCB behaviour in Indonesian SMEs, this study is only limited to workplace factors, person-organization fit, OCB, and employee satisfaction.

\section{REFERENCES}


Achmad, Kuncoro. (2001). How to Use and Interpret Classical Assumption Analysis, First Print. Bandung: ALFABETA.

Arikunto. (2006). Research Procedure A Practice Approach. Jakarta: PT. Rineka Cipta.

Arikunto. (2009). Research procedure. Jakarta: PT. Rineka Cipta.

Astuti, Darmi Sih. (2010). "Model Person Organization Fit (PO Fit Model) on Employee satisfaction, Organizational Commitment, and Employee Performance". Journal of Business and Economics (JBE). Vol. 17 No.1

Azeem, Syed Mohammad. (2010). "Employee satisfaction and Organizational Commitment among Employees in the Sultanate of Oman". Journal Psychology, Vol. 1. p. 295-299.

Dergibson Siagian and Sugiarto. (2000). Statistical Methods for Business and Economics. Jakarta: PT Gramedia Pustaka Utama

Dotan, H. (2007). Friendship Ties at Work: Origins, Evolution, and Consequences for Managerial Effectiveness. University of California, Los Angeles. Los Angeles, CA

Tisnawati, Ernie. (2005). Introduction to Management, First Edition. Depok: Prenadamedia Group.

Echdar, Saban. (2017). Management and Business Research Methods. Bogor: Ghalia Indonesia

Fehr, B. (1996). Friendship processes. Thousand Oaks, CA: Sage.

Fine, G. (1986). Friendship in the workplace. In VJ Derlega, and

BA Winstead (Eds.). Friendship and Social Interaction (pp. 185- 206). New York, NY: Springer- Verlag.

Garay, HDV (2006). Extra-Role Performance and Compensation Policy, SINERGI, Business, and Management Review, 8(1), pp. 21-32.

Ghozali, Imam. (2000). Multivariate Analysis Application with SPSS Program. Semarang: UNDIP Publishing Agency

Greenberg, J. And Robert A. Baron. (2003). Behaviour in Organization International Edition, New Jersey: Prentice-Hall.

Kreitner, Robert, and Angelo Kinicki, (2001). Organizational Behaviour. Fifth Edition. USA: McGraw-Hill.

Kristof, AL (2013). Person-organization fit: An Integrative Review of its Conceptualizations, Measurement, and Implications. Personnel Psychology, 49(1), pp. 1-49. 
Malayu, SP Hasibuan, (2007). Management Resources of Man Power. Jakarta: PT. Earth Literacy.

Meyer, P. John., And Herscovitch, Lynne. (2001). Commitment in the Workplace Toward a General Model. Human Resource Management Review, 11, pp. 299-326.

Nielsen, IK, Jex, SM, \& Adams, GA (2000). Development and Validation of Scores on a Twodimensional Workplace Scale. Educational and Psychological Measurement, 60, pp. 628-643.

Organ, DW (1994). Personality and Organizational Citizenship Behaviour. Journal of Management, 20, pp. 465-478.

Riduwan \& Akdon. (2009). Formulas and Data in Statistical Analysis. Bandung: Alfabeta.

Riduwan, (2010). Measurement Scale of Research Variables. Bandung: Alfabeta.

Robbins SP, and Judge. (2008). Organizational Behaviour of Book 2, Jakarta: Salemba Empat.

Silverthorne, Colin. (2004). The Impact of Organizational Culture and Person Organization Fit on Organizational Commitment and Employee satisfaction in Taiwan. The Leadership \& Organization Development Journal, 25, (7), 592-599.

Song, S. (2005). Workplace and its Impact on Employees' Positive Work Attitudes: A Comparative Study of Seoul City and New Jersey State Government Public Officials. Rutgers, The State University of New Jersey. Newark, NJ.

Sugiyono. (2014). Educational Research Methods with Quantitative Approaches, Qualitative, and $R \& D$. Bandung: Alfabeta.

Uhl-Bien, Mary, Schermerhorn, Jr., John R., Osborn, Richard N. (2014). Organizational Behaviour, Experience Grow Contribute (13th ed). 222 Rosewood Drive, Danvers, MA 01923: Clearance Center, Inc.

Van Dyne, L., Graham, J. W., \& Dienesch, M (2003). Organizational Citizenship Behaviour: Construct Redefinition, Measurement, and Validation. Academy of Management Journal. 37 (4), pp. 268-277. 